\title{
3. Managing residential water demand in the OECD
}

\author{
Michael Ward \\ Monash University, Australia
}

Chris White

The Australian National University, Australia

Water scarcity is a growing concern in many cities due to rapid population growth, rising incomes and the associated increasing demand for water, and increasingly variable water supplies resulting from changes in the global climate.

Due to the economic and environmental costs of large-scale investments in water supply, together with the significant time required for planning and implementation, many urban areas are seeing increasing use of policy measures designed to regulate urban water demand. This research looks at the effectiveness of these demand-side policy measures on residential water demand in the countries of the Organisation for Economic Co-operation and Development (OECD).

According to standard economic theory, the most efficient way to regulate water demand is through volumetric prices (Grafton and Ward 2008). Under such a system, users pay a charge for each unit of water consumed, as opposed to water tariffs, which charge users a block rate depending on the level of their consumption. By using volumetric charges, the water price can be raised during times of scarcity so that users consume less water, thereby reducing demand when supplies are low (Ward et al. 2011).

Due, however, to concerns over the equity of using water prices to regulate demand, and claims that residential water use is unresponsive to changes in price, many water utilities focus on non-price approaches. These include requirements or subsidies for using water-saving devices, such as low-flow shower heads and dual-flush toilets, and the use of public information campaigns to promote water conservation attitudes, such as taking showers instead of baths.

Mandatory water restrictions are an additional non-price approach that is sometimes used to regulate water demand during times of water scarcity. While effective, they can generate significant welfare losses for water users and, as such, was not considered in this research (Ward et al. 2011). 
In order to understand the impact of volumetric prices, water-saving devices, and water conservation attitudes on residential water use, data was analysed from an OECD survey of 1600 respondents across ten countries looking at the price and non-price determinants of residential water demand (Grafton et al. 2011). Respondents were asked a series of questions regarding the following factors: (1) household characteristics (such as age, income, household size); (2) environmental attitudes (such as whether they are members of an environmental organisation); (3) adoption of water-saving behaviours (such as whether they turn off the water while brushing their teeth); (4) use of water-saving devices (such as rainwater tanks); and, (5) domestic water use (such as water consumption, total water cost).

Once the surveys were completed the results were collected and analysed in order to answer three key questions:

(1) What are the impacts of price on household water consumption?

(2) What are the impacts of water-saving devices on household water consumption?

(3) What are the impacts of attitudinal characteristics and environmental concerns on household water consumption?

\section{Impacts of price on household water consumption}

The analysis of the survey data revealed that water demand was inelastic and statistically significant from zero across all ten OECD countries. The price elasticity of demand ranged from a low of -0.27 for Norway, to a high of -0.59 for Italy, while the average price elasticity across the entire sample was -0.43 . A ten per cent increase in the average water price across households, therefore, lowers urban water use in the OECD by about 4.3 per cent. This finding supports the economic principal that the higher the average volumetric price of water, the lower household water consumption will be (see Figure 1).

The results also suggest that volumetric charges are the most important cause of respondents engaging in water-saving behaviours, such as turning off the water while brushing teeth, taking a shower instead of a bath, watering the garden in the coolest part of the day, and collecting rainwater and recycling wastewater. The estimated water savings for households facing volumetric water charges as a result of these water-saving behaviours was around 40 kilolitres each year, or a quarter of the average household water consumption in the OECD. 


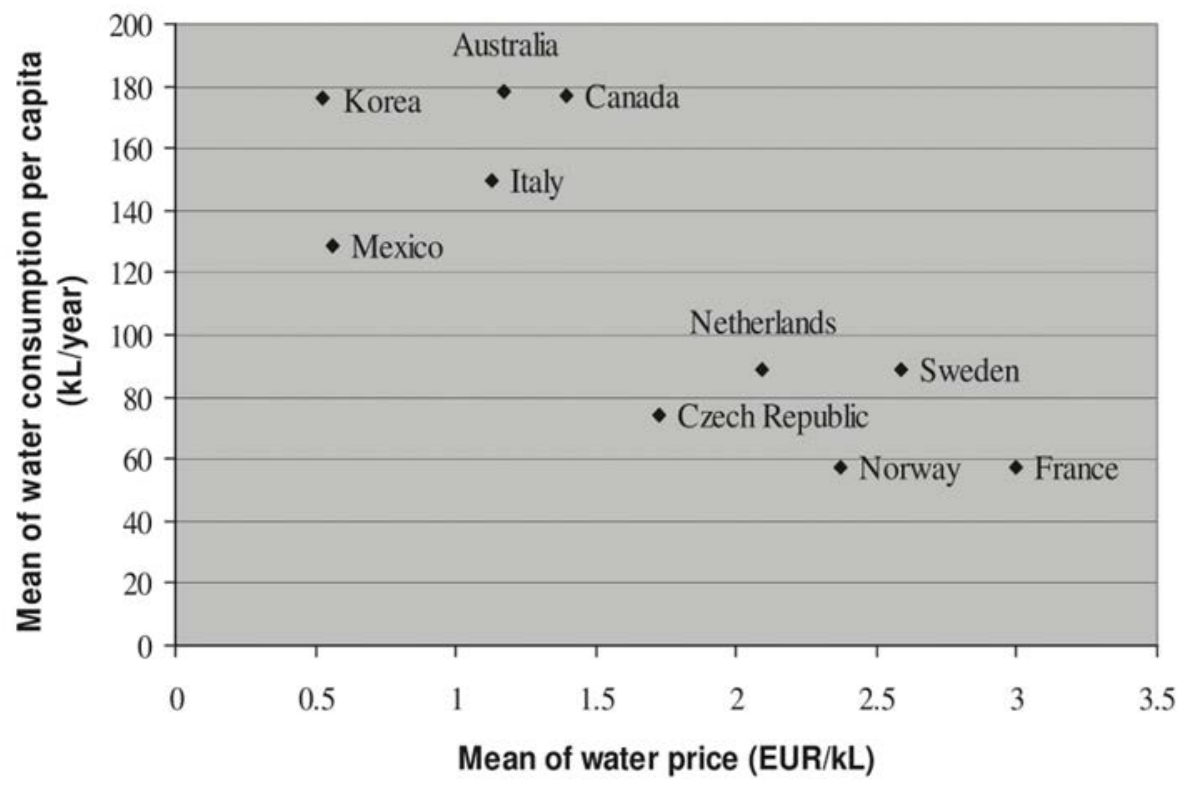

Figure 1: Average water consumption per capita and volumetric price across ten OECD countries

Source: Adapted from Grafton et al. 2011.

\section{Impacts of water-saving devices on household water consumption}

The analysis of the survey data revealed that only dual-flush toilets have a statistically significant and negative impact on water consumption. The coefficient on the dual-flush toilet variable was -0.25 and statistically significant at the one per cent level. This suggests that the use of water-efficient toilets reduces household water consumption by about 25 per cent. By contrast, lowflow shower heads and rainwater tanks did not have a statistically significant impact on household water consumption.

While it initially seems intuitive that water-saving devices should reduce household consumption, this may not necessarily be true in every case. This is because an increase in the water efficiency of a device effectively reduces the unit cost of using it and, as a result, can cause an increase in its use. Olmstead and Stavins provide a review and summary of several studies on water saving devices and also find that the impact of such devices on water consumption is mixed (Olmstead and Stavins 2009). 


\section{Impacts of attitudinal characteristics and environmental concerns on household water consumption}

The analysis of the survey data did not reveal significant evidence of the influence of environmental concerns and behaviours on household water consumption. Attitudinal characteristics and environmental concerns were, however, found to increase the use of dual-flush toilets, which significantly reduces water consumption.

Some environmental behaviours were found to have a statistically significant and positive effect on the probability of undertaking water-saving behaviours. For example, being a member of an environmental organisation or a supporter of an environmental organisation increased the probability of turning off water while brushing teeth, plugging the sink when washing dishes, watering the garden in the coolest part of the day, and collecting rainwater/recycling wastewater. Higher levels of environmental concern were also found to be statistically significant in terms of increasing the probability of undertaking a range of water-saving behaviours.

\section{Policy implications}

Overall, the results suggest that volumetric water pricing is one of the most effective policy measures available to regulate household water consumption. The results also suggest that water-demand management policies, which combine a volumetric charge for water use and a higher average water price with campaigns to promote water-saving behaviours (such as taking showers instead of baths) and the use of water-saving devices (particularly dual-flush toilets) would further improve the regulation of residential water demand.

Michael Ward is Professor in Economics at Monash University, Australia. After receiving a $\mathrm{PhD}$ in Economics from the University of Washington, he has published across a number of economic disciplines in some of the world's leading journals. In 2008, his paper with Jay Shimshack and Tim Beaty was selected as the 'Best Economics Paper' by the Agricultural and Applied Economics Association for work in the area of food safety and nutrition. The article is based on an original piece of research published in Water Resources Research, 'Determinants of residential water consumption: evidence and analysis from a 10-country household survey'.

Chris White is Managing Editor of the Global Water Forum and also works as a Research Associate at The Australian National University and as an Environmental Economist at URS, London. 


\section{References}

Grafton, R.Q. and Ward, M.B., 2008. 'Prices versus rationing: Marshallian surplus and mandatory water restrictions', Economic Record, 84:S57-S65.

— Ward, M.B., To, H. and Kompas, T., 2011. 'Determinants of residential water consumption: evidence and analysis from a ten-country household survey', Water Resources Research, 47:W08537.

Olmstead, S.M. and Stavins, R.N., 2009. 'Comparing price and nonprice approaches to residential water conservation', Water Resources Research, 45:W04301.

Ward, M.B., O'Donohue, J. and Grafton, R.Q., 2011. 'Prices versus rationing of urban water: is there an equity-efficiency trade-off', Centre for Water Economics, Environment, and Policy Working Paper, The Australian National University. 
This text taken from Global Water: Issues and Insights by R. Quentin Grafton, Paul Wyrwoll, Chris White and David Allendes, published May 2014 by ANU Press, The Australian National University, Canberra, Australia. 